\title{
Susceptibility of Gyropsylla spegazziniana (Lizer \& Trelles) (Hemiptera: Psyllidae) to Beauveria bassiana (Bals.) Vuill.
}

\author{
Suscetibilidade de Gyropsylla spegazziniana (Lizer \& Trelles) (Hemiptera: \\ Psyllidae) a Beauveria bassiana (Bals.) Vuill.
}

\author{
Luis Francisco Angeli Alves ${ }^{1 *}$, Marina Andressa Formentini ${ }^{1}$, André Luis Pereira Fanti ${ }^{1}$, \\ Maria Elena Schapovaloff ${ }^{2}$, Ionete Lúcia Milani Barzotto ${ }^{1}$
}

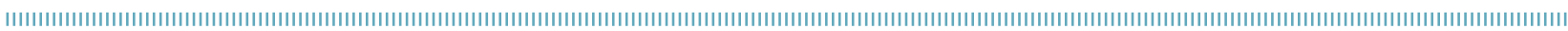

\begin{abstract}
Gyropsylla spegazziniana is one of the most prominent pest insects of yerba mate culture in all production regions in Brazil, Argentina and Paraguay. Natural enemies have been recorded on $G$. spegazziniana nymphs and adults, including the Zoophthora radicans entomopathogenic fungus. Since there are no reports of Beauveria bassiana, the aim of this study was to register its pathogenicity with respect to this insect in a laboratory setting. Yerba mate branches were kept in glass flasks with water and we infested each leaf with 20 newly-emerged nymphs. We prepared three replicates per treatment. We sprayed conidia suspensions $\left(1 \times 10^{9}\right.$ conidia $\left./ \mathrm{mL}\right)$ onto the branches, which we transferred to cages and kept in an acclimatized room (26 \pm $1{ }^{\circ} \mathrm{C}, 70 \pm 10 \%$ of relative humidity (R.H.) with a photophase of 14 hours). We evaluated insect mortality daily, and after five days we observed a high level of pathogenicity due to the presence of the fungus, that could be visually observed on the cadaver. The total mortality varied from 25 to $70 \%$ (respectively for Unioeste 4 and CG 716) and the confirmed mortality was $30 \%$ for Unioeste 52, revealing the fungus' potential. However, more studies are necessary in order to evaluate the strains of this fungus, as well as other species.
\end{abstract}

KEYWORDS: Ilex paraguariensis; entomopathogenic fungi; biological control.
RESUMO: Gyropsylla spegazziniana é uma das principais pragas da cultura de erva-mate em todas as regiōes produtoras do Brasil, da Argentina e do Paraguai. Inimigos naturais têm sido registrados sobre ninfas e adultos de $G$. spegazziniana, incluindo o fungo entomopatogênico Zoophthora radicans. Como não há relatos sobre Beauveria bassiana, o objetivo deste estudo foi registrar sua patogenicidade sobre esse inseto em condiçóes de laboratório. Ramos de erva-mate foram infestados com insetos e mantidos em frascos de vidro com água. Cada um dos ramos tinha cerca de 20 ninfas recém-emergidas/ folha, sendo preparadas 3 repetiçôes/tratamento. As suspensóes dos isolados do fungo $\left(1 \times 10^{9}\right.$ conídios $\left./ \mathrm{mL}\right)$ foram pulverizadas sobre os ramos, que foram transferidos para gaiolas e mantidos em sala climatizada $\left(26 \pm 1^{\circ} \mathrm{C}, 70 \pm 10 \%\right.$ de Umidade Relativa (U.R.) e 14 horas de fotofase). Diariamente, realizou-se a avaliaçáo da mortalidade do inseto, observando-se, após cinco dias da aplicação, alto nível de patogenicidade devido à presença do fungo, constatada visualmente sobre os cadáveres. A mortalidade total variou entre 25 e $70 \%$ (respectivamente para Unioeste 4 e CG 716) e a mortalidade confirmada foi de $30 \%$ para o isolado Unioeste 52 , revelando o potencial do fungo. No entanto, mais estudos sáo necessários para avaliar novos isolados do fungo, bem como outras espécies.

PALAVRAS-CHAVE: Ilex paraguariensis; fungos entomopatogênicos; controle biológico.

\footnotetext{
'Universidade Estadual do Oeste do Paraná (UNIOESTE) - Cascavel (PR), Brazil.

${ }^{2}$ Universidad Nacional de La Plata - La Plata, Argentina.

*Corresponding author: luis.alves@unioeste.br

Received on: 06/09/2011. Accepted on: 04/07/2013
} 
Gyropsylla spegazziniana (Lizer \& Trelles), known as "ampoule-of-yerba-mate", is one of the most important insect pest of yerba mate plantation in all producing regions of South America. This insect attacks yerba mate sprouts of all ages, sucks the plant's sap, inoculates toxins during oviposition, and forms galls called ampoules, which protect the nymphs as they develop inside it. As a result of the attack, deformed leaves generally fall, and the plant spends its nutritional reserves on the generation of new sprouts. If attacks occur in new plants, they show reduction and delay in development. Also, the insect reduces the culture's profitability - there is a recorded production loss of up to $35 \%$ in Argentina (OgLOBIn, 1929; Diaz, 1997; Iede; Machado, 1989; Chiaradia; Milanez, 1997; Gallo et al., 2002).

The insect's cryptic habit associated to the absence of chemical insecticides registered for the use in Brazilian yerba mate culture (Agrofit, s.d.) makes control difficult. Still, some cultural practices are recommended, such as pruning the infested branches and practicing equilibrated fertilization, avoiding nitrogen excess (Diaz, 1997; Iede; Machado, 1989; Penteado, 1995; Ribeiro, 2005).

Alternatively, parasitoids and predators have been reported in Brazil and Argentina (SAIni; De Coll, 1993; Soares, 1994; Diaz, 1997; Chiaradia et al., 2000; Leite et al., 2007; Borges; Lazzari, 2008). As for the entomopathogens, Sosa-Gómez et al. (1994) reported, in yerba mate cultures in Corrientes Province, Argentina, infection of the Zoophthora radicans (Brefeld) fungus in up to $90 \%$ of the ampoule-of-yerba-mate adults. In Brazil, Alves et al. (2009) also reported this association in a yerba mate culture in the municipality of Cascavel, State of Paraná, with similar levels of occurrence in this population. These are the only records of entomopathogens on $G$. spegazziniana.

In spite of their efficiency, entomophthoralen fungi are characterized by their complexity and high scale production. On the other hand, Beauveria bassiana and Metarhizium anisopliae fungi are known for the diversity of hosts, the efficiency against several pests and the ease of production and formulation processes (Alves, 1998). However, there are no reports of natural occurrence of such species on the ampoule bug, or of its potential as a controlling agent.

It is important to mention that there are several studies that prove $B$. bassiana efficiency in the field as a controlling agent of yerba mate pests, such as Hedypathes betulinus (Kluger) (Coleoptera: Cerambycidae) (Leite et al., 1998; 2003; 2006).

Thus, this study aimed to register the first evaluation of pathogenicity of $B$. bassiana on the ampoule-of-yerba-mate, in laboratory conditions, addressing its future use in controlling this pest.

Yerba mate branches with closed galls were collected in a commercial planting and put in glass containers with water $(60 \mathrm{~cm}$ tall $\times 40 \mathrm{~cm}$ wide $\times 40 \mathrm{~cm}$ long), stored in an acclimatized room $\left(26 \pm 1^{\circ} \mathrm{C}, 70 \pm\right.$ $10 \%$ of relative humidity (R.H.) and 14 hours of photophase). With a wet brush, about 20 newly-emerged adults were transferred to yerba mate branches, which were put in Erlenmeyer flasks with water to maintain the leaves' turgidity.

B. bassiana strains: Unioeste 4, Unioeste 52 and CG 716 isolates were cultured in Petri dishes with Beauveria spp. culture media spore production (Alves, 1998), and incubated for 10 days at $26 \pm 1{ }^{\circ} \mathrm{C}$ with a 14 -hour photophase. After this period, conidia were collected and stored in glass tubes at $-10^{\circ} \mathrm{C}$. Conidial viability was checked as in Alves et al. (1998). We suspended the conidia in distilled water + Tween $800.01 \%$, adjusted to $1 \times 10^{9}$ viable conidia per $\mathrm{mL}$.

Samples containing $1 \mathrm{~mL}$ of each suspension of entomopathogenic fungi strains were pulverized onto branches already containing insects with an airbrush coupled with a continuous airflow compressor $\left(6.93 \times 10^{5} \mathrm{kgf} / \mathrm{m}^{2}\right)$ at a distance of $10 \mathrm{~cm}$ from the leaves. After that, the branches were transferred to wooden cages and maintained in acclimatized room $\left(26 \pm 1^{\circ} \mathrm{C}\right.$, $70 \pm 10 \%$ of R.H. with a photophase of 14 hours). For each one of the isolates, three branches were prepared, each of them considered a repetition. For the control, the branches were sprayed with distilled water + Tween $800.01 \%$. Mortality was checked daily for five days and cadavers were collected, which we then immersed in $70 \%$ ethyl alcohol to sterilize the surface, rinsed twice in distilled water and transferred to a wet chamber in order to confirm the mortality by the fungus, incubated under the aforementioned conditions.

Normal distribution was checked with the ShapiroWilk test for normality ( $\mathrm{p}$-value $=0.3901$ ); the obtained data were analyzed by ANOVA and the mortality means were compared through Tukey test, with both at $5 \%$ significance, using the SISVAR statistical software (Ferreira, 2011).

We observed insecticidal activity for all evaluated entomopathogenic fungal strains, especially for Unioeste 52 and CG 716, which caused, respectively, 60 and 70\% of total mortality (Table 1). Although fungal presence had been visually verified on cadavers, the confirmed mortality was lower than the total mortality, with the highest value of $30 \%$ for Unioeste 52 .

In spite of the low level of confirmation, the total mortality obtained with the CG 716 strain may be considered a satisfactory result because the same strain presents activity 
Table 1. Mortality of Gyrospsylla spegazziniana by different Beauveria bassiana strains, five days after inoculation $\left(26 \pm 1^{\circ} \mathrm{C}, 70 \pm\right.$ $10 \%$ of relative humidity (and 14 hours of photophase).

\begin{tabular}{lccc} 
Isolated & Origin & Total mortality & Confirmed mortality \\
CG 716 & Hedypathes betulinus Adult, Ivaí, PR & $70.4 \pm 8.83 \mathrm{~A}$ & $19.6 \pm 3.67^{\mathrm{AB}}$ \\
\hline Unioeste 4 & $\begin{array}{c}\text { Alphitobius diaperinus Larvae, } \\
\text { Cascavel, PR }\end{array}$ & $25.6 \pm 2.23^{\mathrm{B}}$ & $8.9 \pm 2.20^{\mathrm{B}}$ \\
& $\begin{array}{c}\text { A. diaperinus larvae } \\
\text { Unioeste 52 }\end{array}$ & $60.0 \pm 6.93^{\mathrm{A}}$ & $30.0 \pm 4.0^{\mathrm{A}}$ \\
\hline Control & -- & $10.0 \pm 2.13^{\mathrm{C}}$ & $0.0 \pm 0.00^{\mathrm{C}}$ \\
\hline C.V. (\%) & & 10.00 & 21.40 \\
\hline
\end{tabular}

Means ( \pm Standard error) followed by the same letter in the column are not different from each other at $5 \%$ level of significance by Turkey’s test $(p<0.05)$.

against the yerba mate borer $H$. betulinus (LeITE et al., 2003; 2006; BORGES, 2007), increasing its future chance to also be used against ampoule-of-yerba-mate insect.

However, these results also indicate the need for studies assessing new species and strains of entomopathogenic fungi.

\section{ACKNOWLEDGEMENTS}

We are very thankful to the Research Support Foundation of the State of Paraná (Araucaria Foundation), CAPES and $\mathrm{CNPq}$ for the financial support granted to the research on the biological control of yerba mate pests.

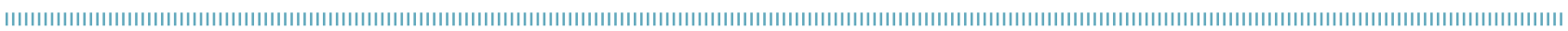

\section{REFERENCES}

AGROFIT - SISTEMA DE AGROTÓXICOS FITOSSANITÁRIOS. Disponivel em: <http://extranet.agricultura.gov.br/agrofit cons/principal_agrofit_cons>. Acesso em: 24 jun. 2013.

ALVES, L.F.A.; LEITE, L.G.; OLIVEIRA, D.G.P. Primeiro registro de Zoophthora radicans (Entomophthorales: Entomophthoraceae) em adultos da ampola-da-erva-mate, Gyropsylla spegazziniana Lizer \& Trelles (Hemiptera: Psyllidae), no Brasil. Neotropical Entomology, v.38, n.5, p.697-698, 2009.

ALVES, S.B. Fungos entomopatogênicos. In: ALVES, S.B. (Ed.). Controle microbiano de insetos. Piracicaba: FEALQ, 1998. p.289-381.

ALVES, S.B.; ALMEIDA, J.E.M.; MOINO JR., A.; ALVES, L.F.A. Técnicas de laboratório. In: ALVES, S.B. (Ed.). Controle microbiano de insetos. Piracicaba: FEALQ, 1998. p.637-711.

BORGES, L.R. Eficiência de Beauveria bassiana (Bals.) Vuill. (Deuteromycota) para o controle de Hedypathes betulinus (Klug) (Coleoptera: Cerambycidae) em erva-mate, Ilex paraguariensis St. Hil. (Aquifoliaceae). 2007. 102f. Tese (Doutorado em Ciências Biológicas) - Curso de Pós-Graduação em Entomologia, Universidade Federal do Paraná, Curitiba, 2007.

BORGES, L.R; LAZZARI, S.M.N. Flutuação populacional de Gyropsylla spegazziniana (Lizer y Trelles) (Hemiptera, Psyllidae) em dois sistemas de cultivo e erva-mate, Ilex paraguariensis A. St. Hil. (Aquifiliaceae). Floresta, Curitiba, v.38, n.2, p.325-330, 2008.

CHIARADIA, L.A.; MILANEZ, J.M. Atratividade de armadilhas coloridas a Gyropsylla spegazziniana (Lizer, 1917) (Homoptera, Psyllidae). Pesquisa Agropecuária Gaúcha, v.3, n.2, p.183-185, 1997.
CHIARADIA, L.A; MILANEZ, J.M.; SABEDOT, S.M. Caracterização e danos da ampola-da-erva-mate. Pesquisa Agropecuária Gaúcha, v.13, p.50-53, 2000.

DIAZ, C.Y.F. Perspectivas del manejo integrado de plagas em yerba mate. In: REUNIÃO TÉCNICA DO CONE SUL SOBRE A CULTURA DA ERVA-MATE, 2., 1997, Curitiba, PR. Anais. Curitiba: 1997. p.371-390.

FERREIRA, D.F. Sisvar: a computer statistical analysis system. Ciência e Agrotecnologia, Lavras, v.35, n.6, p.1039-1042, 2011.

GALLO, D.; NAKANO, O.; NETO, S.S.; CARVALHO, R.P.L.; BAPTISTA, G.C. de; FILHO, E.B.; PARRA, J.R.P.; ZUCCHI, R.A.; ALVES, S.B.; VENDRAMIM, J.D.; MARCHINI, L.C.; LOPES, J.R.S.; OMOTO, C. Entomologia agrícola. Piracicaba: FEALQ, 2002, 920p.

IEDE, E.T.; MACHADO, D.C. Pragas de erva-mate (Ilex paraguariensis St. Hil.) e seu controle. Boletim de Pesquisa Florestal, n.18/19, p.51-60, 1989.

LEITE, M.S.P.; ZANOL, K.M.R.; IEDE, E.T.; PENTEADO, S.R.C. Flutuação populacional de Gyropsylla spegazziniana (Lizer $\&$ Trelles) (Hemiptera, Psyllidae) e de seus inimigos naturais em erva-mate no município de São Mateus do Sul, PR, Brasil. Revista Brasileira de Entomologia, São Paulo, v.51, n.4, p.520523, 2007.

LEITE, M.S.P.; IEDE, E.T.; PENTEADO, S.R.C.; GRIGOLETTI, A.J.; CASTELLANO, C. Seleção de linhagens de Beauveria spp. patogênicas a Hedypathes betulinus (Klug, 1825) (Coleoptera: Cerambycidae), em laboratório. In: CONGRESSO BRASILEIRO 
DE ENTOMOLOGIA, 17., 1998, Rio de Janeiro, RJ. Anais. Rio de Janeiro: 1998. p.767.

LEITE, M.S.P.; IEDE, E.T.; PENTEADO, S.R.C.; ZALESKI, S.R.; CAMARGO, J.M.; RIBEIRO, R.D. Eficiência de fungos entomopatogênicos no controle de Hedypathes betulinus (Klug, 1825) (Coleoptera: Cerambycidae), em laboratório. In: CONGRESSO BRASILEIRO DE ENTOMOLOGIA, 21., 2006, Recife, PE. Anais. Recife: 2006.

LEITE, M.S.P.; PENTEADO, S.R.C.; OLIVEIRA, S. Eficiência do fungo Beauveria bassiana (Bals.) Vuill. no controle de Hedypathes betulinus (Klug, 1825) (Coleoptera: Cerambycidae), em campo. In: CONGRESSO SUL-AMERICANO DE ERVA-MATE, 3., 2003, Chapecó, SC. Anais. Chapecó: 2003. CD-ROM.

OGLOBIN, A.A. La Methaphalara spegazziniana (Lizer) e sus perniciosos efectos. Revista Yerbatera, v.7, p. 15-19, 1929.

PENTEADO, S.R.C. Principais pragas da erva-mate e medidas alternativas para o seu controle. In: WINGE, H.; FERREIRA, A.G.; MARIATH, J.E.A.; TARASCONI, L.C. (Eds.). Erva-mate: biologia e cultura no cone-sul. Porto Alegre: UFRGS, 1995. cap. 2, p. 109-120.

RIBEIRO, M.M. Influência da Adubação Nitrogenada na Incidência de Gyropsylla spegazziniana. 2005. $151 \mathrm{f}$. Tese (Doutorado em Engenharia Florestal) - Curso de Pós-Graduação em Engenharia Florestal, Universidade Federal do Paraná, Curitiba, 2005.

SAINI, E.D.; DE COLL, O.R. Enemigos naturales de los insectos y ácaros perjudiciales al cultivo de la yerba mate en la República Argentina. Montecarlo: E.E.A. - INTA, 1993. 32p.

SOARES, C.M.S. Ocorrência de Halictophagus sp. (Strepsiptera: Halictophagidae), parasitóide de adultos de Gyropsylla spegazziniana (Homoptera: Psyllidae). In: SIMPÓSIO DE CONTROLE BIOLÓGICO, 4., 1994, Gramado, RS. Anais. Gramado: 1994. p.237.

SOSA-GÓMEZ, D.R.; KITAJIMA, E.W.; ROLON, M.E. First records of entomopathogenic diseases in the Paraguay tea agroecosystem in Argentina. Florida Entomologist, v.77, n.3, p.378-382, 1994. 